\title{
[8]
}

\section{Folk Religions, Old and New}

The folk religion practiced by Taiwanese people is a local variant of the many that historically emerged all over China. Although the imperial state imposed some controls on religious customs that challenged authority by growing too unorthodox, Chinese working people have experimented freely with their traditions, adding or dropping elements, reformulating ideas about supernatural beings and their relations with human beings, or inventing and elaborating rituals that express local concerns. In Taiwan, Buddhist and Daoist temples, monasteries, convents, and private religious specialists are locally influential, but there are no strong religious organizations that can unify ritual practice or set dogma. Some Buddhist associations that are dominated by Mainlander clergy, however, make attempts to "purify" local folk ritual to conform to government policy and the customs of their mainland religious training. At times, Japanese and Nationalist officials have tried directly to limit or eliminate certain folk religious customs (see Weller 1985, 1987). By and large, however, folk religion has flourished freely and illuminates exceptionally well the ways Taiwanese people organize themselves and view their world when they are allowed to shape their own institutions.

The little communities in which working-class families prefer to live generally symbolize their unity through worship of a supernatural patron believed to have a special attachment to the area and a concern for its people. Even in Taibei, the largest and most rapidlly growing of Taiwan's cities, urban neighborhoods that have engulfed older town or village nuclei 


\section{Chinese Working-Class Lives}

often contain old shrines or temples around which religious activities cluster.

These temples are of varied origins. In the most common, the Earth God (and Madam Earth God, in some cases) is worshiped. These represent, people say, the lowest level of a heavenly bureaucracy that parallels Taiwan's government. At the top of the government, President Jiang; at the top of Heaven, the Jade Emperor; at the bottom of the government, the neighborhood police station; at the bottom of the hierarchy of gods, the Earth God, responsible for the neighborhood people over which he has been given authority. Between these levels are many earthly and heavenly bureaucrats and ministers, each supernatural with a retinue of spirit generals and soldiers who enforce his will. (Beneath the earth lies another supernatural realm that is "just like Taiwan" except that it is populated by the spirits of the dead and ruled by monstrous spirits who punish their sins.) As the country is divided into administrative units governed by officials, so every neighborhood ought to have its Earth God to report back to his superiors on people's behavior. The various Earth Gods were once human beings of superior virtue. If they conduct themselves well in their posts as Earth Gods, they will be promoted to a higher rank in Heaven. These gods, who are represented by small, brightly painted wooden images of a seated old gentleman in imperial court costume, are housed in small temples that serve as the focus for much community worship.

Some neighborhoods worship other supernatural beings, in addition to or instead of an Earth God, such as higher-ranking gods with larger temples. Communities sometimes also worship dangerous, low-ranking spirits. Little shrines for those who died in battle-against the Aborigines or in the clan wars-are often built over historical mass graves. At a site where someone died violently and unhappily, the ghost may linger in a bad temper, causing harm and illness until it is given a tablet, shelter, and offerings (Harrell 1974). One such shrine, built in the form of a colorful little pagoda, stands not far from Prosperity Settlement, a physical home for the spirit of a slave girl who was beaten to death on the spot by her master nearly a hundred years ago. In the decades since neighborhood people began to pay her spirit respectful attentions, she has become well disposed and protective; they now describe her not as a gui, or ghost, a term with unpleasant connotations, but instead as a shen, a god (see Jordan 1972; A. Wolf 1974).

By conceiving of the "other," supernatural world as organized into a single hierarchy of power and authority, the Taiwanese express their understanding that society itself is structured hierarchically. Inequalities are part of the nature of the cosmos. Everything on earth, in heaven, and in the 
underworld is included in this schema: no evasion of its principles is possible. Humans must obey their superiors and do their duty by those dependent on them.

In Taiwan, where human beings may become gods after death and where any individual or community may decide to worship such a spirit, there are many ways in which a small shrine may grow up. Even a newly developed working-class urban area is likely to be close to an older religious center, or it may establish a new one of its own. Typically, at least once a year the people of the neighborhood celebrate the "birthday" of the patron god or goddess in a festival that strengthens and expands their social ties, "putting the neighborhood on the map" for the rest of society.

Prosperity Settlement, home of about two thousand people, including Mrs. Lim (Chapter 9) and formerly Miss Ong, holds two such festivals each year. Another festival, managed privately for many years by a resident household, also drew heavily on neighborhood support for its success until the manager moved away in the mid-1970s.

On the fifteenth day of the first lunar month of 1972, Prosperity Settlement families celebrated the birthdays of their Earth God and Madam Earth God with the longest and most expensive festival they had ever sponsored, in honor of the new temple they had just built. In preparation for this event an "incense pot master" and four assistants had been chosen the previous year from among the female and male household heads of the community. The god himself selected them, indicating his intentions by the positions of two red wooden blocks thrown repeatedly by the candidates: the person receiving the most "votes" from the god became incense pot master, and those ranking next, his assistants. Families that were impure through death, or women through childbirth, were not eligible to participate.

This group of solid citizens was responsible for planning and supervising the festival, including hiring the Daoist who would perform a necessary ritual. They requested permission from the local police station to hold the event, as no unregistered public gathering was permitted under Taiwan's martial law. Mr. Dan, the incense pot master, filled out the necessary forms and paid the police the necessary bribe. After careful consultation with the others, one of the assistants was deputed to hire three different opera companies for the anticipated fifteen days and nights of performances. These companies were chosen on the basis of reputation and familiarity from one of the many small opera troupes whose members fill in between engagements with other forms of day labor, including funeral miming.

Ten days before the festival date, the leaders visited every Taiwanese household in Prosperity Settlement except for a few extremely im- 


\section{Chinese Working-Class Lives}

poverished ones, approaching even a few sympathetic Mainlander households. From each family they requested a token donation of NT $\$ 4$ (U.S.\$0.10) for each man, woman, and child, listing the family by number of males and number of females under the full name of the household head. Because this sum fell short of the expected costs, the leaders made a second circuit, this time tapping all the owners of the nearby small factories. One, whose paint factory always dumped the last of its current batch of coloring into Prosperity's stream, causing it to flow green, purple, or pink by turns, gave the NT\$3,000 (U.S.\$75) necessary for a whole evening in gratitude for the past year's good business. By concentrating their efforts among the better-off, the leaders were able to reduce their deficit to only a few hundred New Taiwan dollars.

Though a few Mainlanders join the ritual community by making contributions, these celebrations flourish mostly among working-class Taiwanese; many Mainlanders disdain Taiwanese festivals as supersititious and oldfashioned, and either ignore or criticize them as wasteful, as do more educated Taiwanese like Mrs. Lim (Chapter 9) and Mr. Kho (this chapter).

Two days before the festival, a hired crew erected a bamboo and canvas opera stage facing the brilliantly tiled new temple. The neighborhood children immediately took possession, swarming over, swinging from, and jumping off it with great glee.

The morning of the fifteenth, the weather showed a welcome break in the midwinter rains. Very early, the leaders, free from any sexual taint and dressed in freshly washed clothes, walked to a lovely old Goddess of Mercy temple nearby to invite one of her many images to attend the celebration as the community's and the Earth God's guest. After burning incense, the incense pot master invited the goddess to accompany them to Prosperity Settlement, obtaining her assent by throwing the wooden blocks and observing their positions. (Should the answer have been "No," I was told, they would renew their request, ever more respectfully, until a positive answer turned up.) Placing the small wooden image on a stack of spirit money to maintain its purity, the incense pot master carried her out of the temple and back to Prosperity. Here, welcomed with firecrackers, she was installed in the position of an honored guest on the Earth God's altar.

On this important occasion, the altar was particularly beautiful, decorated with symmetrical vases of bright gladiolus and fragrant ginger flowers, fresh candles, and large platters of beautifully colored fruit. On one wall glowed a cheerful neon sign of a peach and the character for "long life" which a local businessman always lends. Over the door hung a red "Eight Immortals" banner, embroidered with legendary Daoist figures. The older women and men of the neighborhood bustled in and out, offering un- 
solicited advice and unstinted criticism, carefully depositing their own god images, hanging up a great incense coil as a family offering to the assembled supernaturals, and generally having their say. There are rules for rituals, but as few people completely agree on what they are, there was plenty of room for rearrangement, additions, and the airing of opinions. Many settled in for a few minutes to sit on a bench or stool by the door and enjoy the "hot noise" of a lively, happy crowd.

Meanwhile, outside the temple, a muscle-bound butcher prepared two large pigs as offerings. While in the old days, Prosperity people raised their own pig sacrifices, it was now illegal to keep livestock in the city limits, so the pigs arrived with the hired butcher as gutted carcasses paid for by two competitive groups of neighbors. In front of the temple, the butcher maneuvered them over the temple's stretching racks, making them appear twice as fat as they were, and began to decorate them. Already covered from snout to hams with red slaughter-tax seals, they were adorned with small pineapples in their mouths, live, flapping fish suspended from their jaws, necklaces of old coins and new money, and a prickly scatter of national flags stuck into their shoulders. Through the morning, they stood as symbols of spiritual salvation-even a lowly pig can become a worthy offering to the gods-the grandest sacrifice a god can receive (Ahern 1981a). By the afternoon, the butcher was rapidly disassembling these handsome beasts into neat, numbered, and precisely equal piles. As dusk fell, they were distributed by lottery and soon converted into dinner.

Meanwhile, during the afternoon, the opera began. The loud music and firecrackers that announced it drew people from their houses, the older ones carrying chairs or stools for comfort. During the day, old people and preschool children formed an appreciative audience for historical moralistic tales, while the younger evening crowd preferred romantic operas laced with satire and wit.

Toward evening, as the opera tootled and gonged its way through a Confucian plot, mothers-in-law and wives began to appear to set their family's special festival dinner down before the gods as an offering. A whole cooked chicken, a duck, and a big chunk of pork was the usual offering, symbolizing, by the largeness and wholeness of the animals, a hope for abundance and family unity in the year ahead. Most women offered small cups of wine as well, drawing the gods' attention to the food and liquor with prayers and incense. When an incense stick had burned down, the donor assumed that the gods had had time to consume the essence of the food. She then repacked the remaining part into a carrying basket, poured the wine back into the bottle, and took the whole kit home for dinner.

People in Prosperity made other offerings, too. Red cakes two feet long in 


\section{Chinese Working-Class Lives}

the shape of turtles were offered, but these were left on the altar and not taken home. A person seeking to improve her family's wealth, health, or fertility could take a turtle home to share with her family, promising the god that if he helped them, they would return two turtles the next year. Typically, in reality, people returned one and contributed an equivalent in money to the incense master's fund. The temple's records for these transactions in Prosperity go back to 1952 , showing increasing expenditure on turtles through the years (Rohsenow 1973:125-26).

The second and succeeding days of the celebration were less lively, for the special offerings were completed. The operas continued, however, providing an opportunity for local people, guests, and gods to savor this traditional and well-loved entertainment.

Toward the end of the festivities, a Daoist arrived to address the god formally in archaic spoken Taiwanese, calling his attention to the contributions people had made. He read off the entire list of household heads, along with the number of males and females in each household and the amount of money they had given, so the Earth God would know the people who were included in his jurisdiction for the next year and would take proper care of them. The list, on red paper, was burned, thereby sending it to Heaven, where the households received proper credit for their individual sums. A second copy was posted on the temple wall for all to see, so there could be no accusations of embezzlement. Settlement people celebrate in this fashion every year at this time, albeit on a smaller scale, as do many neighborhoods throughout the island, each in its own fashion.

Prosperity Settlement's second yearly festival, held on the fifteenth day of the tenth lunar month, celebrates the birthday of a tripartite god, or group of three brother gods, named Sam Gai Gong. Sam Gai Gong has no temple and no image but is represented by an incense pot that "lives" in the house of the current incense pot master. The celebration is similar in most respects to that for the Earth God, except that pigs and turtles are not offered and that on this date Prosperity families invite human guests to feast and watch their opera.

Ordinary households invite two or three tables of guests- two or three dozen people-while the well-to-do in the neighborhood may invite five tables-sixty or more guests. Married-out daughters or sons who live separately, senior collateral relatives, and good friends are invited along with those with whom the family wishes to form a closer relationship: a child's teacher, the business's wholesaler, a handy contact in a government bureau, someone who is owed a favor, someone the family wishes to ask for a favor in the future. These feasts are very important to the family's social and business network, and the household spares no expense to provide 
lavish food, liquor, and cigarettes. The stiffness Chinese often show when strangers gather is greatly loosened by drink, giving the guests opportunities to make new and useful friends. When people speak of festivals, what is central is the food and the sociability of eating together in the honorable relationship of host and guest. As a respected Prosperity family head once said, "Some people really aren't very great believers in the gods. But when a community celebrates this way, it makes us all better neighbors."

Offerings of food and entertainment made to gods convey information about the real world, too. If society is a hierarchy of power, ordinary folk may need the support and protection of important people who can be brought to benevolence by offering them gifts and deference. As Emily Martin [Ahern] has pointed out, the etiquette of dealing with human superiors is codified and taught even to working people through the formal rituals appropriate for petitioning gods (Ahern 1981b).

Large temples, of which there are dozens in Taibei and hundreds on the whole island, hold similar "birthday" celebrations on a grander scale and sponsor other rituals as well. Just as leaders from small neighborhood temples borrow images from larger ones, so do the leaders of mediumranked temples borrow from the oldest and most famous. Hundreds of gods "go visiting" every year from a few temples thought to be especially spiritually powerful, and the leaders who escort them develop relationships that reach throughout the island. At the most famous of these, the Beigang temple to Mazu, a goddess often associated with the sea, the celebrations draw visitors from as far away as the emigrant Taiwanese community in Japan. When thousands of eager pilgrims converge on the dusty little town to watch its dramatic religious processions and to worship in Mazu's riotously ornate main temple, it becomes clear that this totally decentralized folk religion in fact links Taiwanese people into a huge, loose, but very significant organization. Much of the continuing sense of Taiwanese ethnic identity is formed in the ritually defined temple communities with their colorful celebrations stressing locality and sociability.

Working-class Taiwanese often approach their gods to pray for assistance in family matters, getting a job, or bearing a child. Some, however, find the temple setting too impersonal or fear that the gods in them will be too busy to attend to their problems. Or, they may have prayed earnestly to several gods and received no help. Such people often turn to spirit mediums like Mr. Go (this chapter), women and men who, in a trance state, are believed to be possessed by a god who either speaks, writes, or in some other way conveys the god's answers to those who ask him questions.

Mediums are extremely common in Taiwan: there are three or four 


\section{Chinese Working-Class Lives}

within a few minutes' walk of Prosperity Settlement, which is not exceptional. Many set up as small businesses, charging a fee for consultations. Some seem fraudulent, but many give helpful, sensible advice and reassurance and are apparently sincere. One medium whose advice I came to respect warned a client who wanted a charm to protect her toddler from fire that a charm would not help the child. She, the mother, must be vigilant in keeping her away from the low gas rings and charcoal stoves on which Taiwanese women cook. He would, however, give the mother a charm to help her be alert to danger. While some people believe very strongly in certain mediums' abilities to transmit supernatural messages, many are skeptical, assuming that most of these practitioners are merely "doing business."

A clever and effective medium can do a great deal toward raising the prestige of a local god or temple, as Mr. Go did in his neighborhood's Earth God temple. Prosperity Settlement's privately managed festival attracted visitors from distant parts of the city because of its association with a medium who was believed to transmit the patron god's healing powers to worshippers.

Although most variants of folk religion, like those of Beigang and Prosperity Settlement, fit into patterns acceptable to the government, others take on unorthodox or even subversive elements and are banned. Some of these, such as an underground cult called the Duck Egg Religion, invert traditional folk symbolism-using white candles instead of the customary red and allegedly requiring nudity instead of the sexual propriety of orthodox religion-and are officially believed to be corrupting to good social morality. Others, like the Soka Gakkai to which Miss Ong and Mr. Kho (this chapter) are converts, are banned because they might, as in Japan, organize a political party that would successfully compete with the Nationalists.

Christians, who make up about 5 percent of Taiwan's population, are divided among Catholics - mostly Mainlander, conservative, and very acceptable to the government; Presbyterians, mostly elite Taiwanese, sensitive to political repression and objects of suspicion to the government; and a fantastic assortment of other minor sects. ${ }^{1}$ While working-class Mainlanders are often Catholic or atheist, most permanently settled working-class Taiwanese follow community temple ritual. That transients and squatters

1. Since the early 1950s, Taiwan has had a great superfluity of missionaries who were formerly posted to the mainland. Although they are not successful in making converts, many American churches keep them on in Taiwan in hopes of gaining a share in anticipated future repayments for mainland church properties seized in the 1949 revolution. 
like Mrs. Lo and Miss Guo do not participate in such activities indicates how much the gods stand as symbols for orderly, settled communities.

Community folk ceremony remains a powerful force in Taiwanese society despite the relative shallowness or even absence of religious belief among its adherents, if only because of its numerous and obvious social functions. Temples define the neighborhoods into which mobile urban people move, and offer them and older residents the opportunity to participate in a virtuous collective endeavor. The genuinely poor can participate in token ways that preserve their dignity and community membership, or they may forgo involvement altogether without being criticized. Suspicious strangers are transformed into known, potentially friendly neighbors, contacts are made with guests from other areas, and the neighborhood's existence, prosperity, and upright morals are advertised. The widely shared foundations of belief are easily restructured or created anew to meet local and individual needs, so even newly built residential areas may choose to become ritual communities. Because many families earn their livelihood as religious specialists, as manufacturers of ritual equipment, and, in pilgrimage centers, from the tourist trade, folk religion is an asset to the working-class economy by redistributing some of the better-off families' wealth to others in the form of food, entertainment, and contacts. From the symbolism and rituals of folk religion, too, people read certain tried-andtrue conclusions about the world: that women and men are deeply different; that hierarchies of power are inevitable and sanctioned by the gods themselves; that by careful etiquette, gift giving, and sharing of food the ordinary people can extend their social networks to enlist the aid of the mighty.

Mr. Go and Mr. Kho, whose life histories follow, are unusually involved in religion: most Taiwanese do not become spirit mediums, nor do they worship in underground sects. But they also illustrate very characteristic patterns of belief among Chinese men. Mr. Go, through organizing and participating in ritual, has made something of a late-life career of folk religion. All the temples and cults of Taiwan are kept alive by the partially self-serving actions of such men, and of rather fewer women. Mr. Kho, like many better-educated Chinese, sees folk religion as childish superstition and has sought a more spiritualized faith. True in spirit, if not in detail, to the Confucian tradition of self-cultivation through reading, philosophizing, and upright personal conduct, Mr. Kho's "foreign" religion in fact permits him to follow the traditional path of the Chinese gentleman.

Miss Ong's religious impulses are also revealing. Like many Chinese working-class women, Miss Ong searches among the religious options open to her for help in bearing an often difficult life. From an enthusiast of 
community festivals, she became a high-minded convert to Mr. Kho's sect and is now a fortune-teller. Taiwan's temples see millions of such women and men, sometimes searching for the meaning of life, sometimes desperate for assistance for the present moment.

\section{Go Cala: Temple Master}

"Did you come to worship the goddess? Today is Mazu's birthday, a great celebration. If you pray to her, she will give you what you ask," said Mr. Go, eager to welcome an unusual American visitor to his small temple's most important event of 1970 .

Above the murmuring of neighborhood worshipers, the joyful noise of the opera performing a few yards away, and the racket of nearby traffic, $\mathrm{Mr}$. Go told me a bit about the three-hundred-year-old Earth God temple that he was planning to expand into a center of worship of Taiwan's favorite goddess, Mazu. For the next ten years, as a retired patriarch in his sixties, Mr. Go planned, raised money, organized work groups, leaned a little on local politicians for donations, rebuilt the temple, and expanded it to include a sort of chapel for Mazu; that accomplished, he led pilgrimages to greater Mazu temples throughout the island to give greater sanctity to her images housed in his temple, trained a group of young men in ritual drum and gong music to play in processions and festivals, and built up a small but flourishing center of Mazu worship over which he presided with expansive geniality.

A short, slight man with small features and hair dyed jet-black, Mr. Go always wears a business suit when he leaves home, careful of the impression he makes on the world. As I visited him over the years to follow the development of the temple and the changes in its neighborhood, we always met rather formally at his little office in the temple. This was his place of business, and he had its dignity as well as his own to consider.

Taiwan's temples are pleasant, shady places to sit and talk on nonfestival days. They smell of incense and, like this one, often have space for a tiny garden, bright amid the bricks and concrete of its old-fashioned workingclass surroundings. The Earth God's temple itself is too small to sit in comfortably, for the altar tables take up most of its 12-foot depth. To me, the white-tilted interior looks a bit like a bathroom, but local people admire it as bright, easy to clean, and pleasingly modern. I preferred to sit outside, in a space that Mr. Go's efforts have provided with a decorated roof upheld by pillars. This shelter, larger than the temple itself, protects its doorway and makes a breezy but rain-free spot for conversation or for displaying 
festival offerings. On the left side, in a glass-fronted shallow room, stand about twenty images of Mazu, plumply benevolent behind fierce spirit generals. Mr. Go's office is squeezed beside them, just leaving space for the narrow alley that leads past several front doors to the street.

When I visited, several other people often sat down to enjoy the relative quiet: an old caretaker, who lived nearby and kept an eye on things when Mr. Go was elsewhere; a few young men, between jobs or looking for a favor from the temple master; a couple of older women escaping the heat of their daughters-in-law's kitchens. It seemed natural to meet there, at Mr. Go's principal place of business. But, despite our many chats, I realized when I decided to include him in this study that I knew little of Mr. Go's personal life outside the temple.

When in 1980 I asked to record his life history, Mr. Go was amused but willing to tell me something of his past. But luck was not with us. One day I missed him, on another my assistant was ill, on a third occasion he was unexpectedly busy. Suspecting that, after all, my request had been politely rejected, I dropped the project. When I returned to say good-bye before returning to the United States, I found him offended that I had not persisted and actually recorded his life. Finally, early in 1985, I was able to complete the task through the kind assistance of Ms. Wang Chunhua, whom he knew as my friend from many earlier visits. She guided the interview with a list of my written questions.

Many men like Mr. Go, after an early life of hard work and raising sons to care for them, retire to a more leisurely career managing and manipulating people. Mr. Go was reserved about his network of patrons and followers, but his account of his life reveals a little about the social groups that gave him a local power base. First, and most obviously, his religious connections were numerous. Virtually anyone, old or young, female or male, can use one of Taiwan's many temples as an arena to attain a degree of local fame (or notoriety). Many young men, and, more rarely, women, become spirit mediums through whom gods speak, offering these services either freely or for pay to the public as Mr. Go did for a time. Older men (and, occasionally, women) are more likely to do as Mr. Go did when he felt that his physical strength was waning and his local power base was broad enough: they build up some local temple by expanding and decorating its buildings, organize bigger and more spectacular festivals, persuade popular spirit mediums to attend them, and arrange for pilgrimages. These activities bring them into contact with many people, including similar men and women in other neighborhoods and communities. Such religious leaders depend on a network of useful social ties, while fund-raising and the giving and receiving of favors extend those ties. As a long-time resident of a neighborhood with an 


\section{Chinese Working-Class Lives}

established temple, Mr. Go had a natural base. By shifting the focus of local worship to the popular goddess Mazu, he was able to take advantage of the enthusiasm of older women for religiously sanctioned travel and turn a static local Earth God temple into the center of expanding social significance.

His colleagues in the building trades were the second group on which he drew for support. Urbanization in Taiwan since the fifties meant prosperity for builders and importance for the older men among them who knew where the jobs were, who could organize work gangs, and who could pass on skills and knowledge to younger men. Mr. Go, as a minor contractor for carpentering jobs, was such a man: he also knew how to pay off the police, building inspectors, and officials who grant building permits in a system where such knowledge is an essential business skill.

These contacts brought him into a political network: the police and other low-level Nationalist officials of Taiwan's large government/party leadership. Men like Mr. Go are essential to Nationalist electoral success in Taiwan, for it is they who deliver the votes of the working-class population. In the 1980 elections the going price of a vote was $\$$ NT200 (U.S.\$5), paid out through established, reliable community leaders who have clout with their neighbors, who can judge dependably which of them will vote as they have been paid to do, and who have too much to lose to attempt to deceive the party men who supply the funds. Those who can dispense this patronage naturally increase their ability to attract donations for temples and find it easier to clear away red tape in the construction business. Mr. Go appears to have benefited from such linkages in his rise as temple master.

I was born in Great Prosperity, on Eternal Spring Street. My family has lived here since they came to Taiwan about one hundred years previously. There have been houses and businesses in Prosperity Settlement and Great Prosperity for many years-since before the Japanese came. We were not farmers here, but workers like carpenters and miners or shopkeepers. My grandfather was a carpenter who made wardrobes and closets, my father followed his trade, and so did my elder brother and I. For three generations in our family we have done the same thing. Grandfather and Father ran their own businesses, as did I before I retired. But while Grandfather got rich, Father became poor. He just got by, from day to day, and couldn't hope to have savings.

We were three brothers-one older than I and one younger. Though I used to have relatives living around here, now everyone has bought his own house and moved away. My mother didn't work outside the home; in the past, women stayed home taking care of the children, and didn't work at all. 
I didn't go to school, but got into business peddling very young. I sold cakes and small things on the street. It was like today's street peddlers-I had to keep moving to make sales, and when the police came, I ran away. I tried a lot of different things - everything I could think of My older brother was building houses, so I learned to do that. We built Japanese-style houses, all one floor.

But for a while, when I was about twenty, I belonged to a zhentou-an old-fashioned Taiwanese band that played opera at festivals. When people hired us, I played. It was irregular work. I also acted in operas, learning one role at a time, altogether learning only two or three operas. I played women's parts, because at that time, there were no women actors. Younger men played women's roles. It was fun, for a while, for me and for the villagers we played for. I didn't have any pictures taken of me acting at that time; it would have been more than forty years ago.

That was during the Japanese time. I knew some Japanese people and generally admired them. They were straightforward, and when something needed doing, they went ahead and did it. Life was not so easy for me then, though, especially during the war.

In the years before the war, I worked again building Japanese houses. After Retrocession I built both Japanese and Chinese styles. When we built, a head craftsman told us what to do. I sometimes think that he didn't need to have a specific skill-he just did the design. Before the war, there was a lot of house-building, so we had a lot of business. During the war, there wasn't any building, so I went back to work as a miner. I didn't go back to building until the economy got better in the fifties.

I worked as a coal miner in Shiwufen, in Taibei County. It was an hour's walk from our house; there were no cars then, so I walked to work. I did that for seven years. As a coal miner, I earned between sixty and seventy yen a month, two or three yen a day. That was a good job, better than being a house-construction worker where I earned only a little more than thirty yen a month-1.1 yen a day. Unskilled workers got 0.48 yen a day, but most people were skilled and earned 1.1.

Late in the war, I went into the Japanese Navy, serving for six months. I was the only man in my family to be in the service, and one of only eightyseven men in the whole city of Taibei who were in the navy. It was pretty good. It paid 5.50 yen a day. I made airplanes in the south of Taiwan and was stationed in Yilan for a couple of weeks.

During the war the government allocated food to people, including the Japanese - pork and other kinds of food. They gave enough for about twenty days out of the month - the other ten days' food people had to get what they could for themselves. My family would buy sweet potatoes from the south 
in the Wanhua district of Taibei. During the war there was never enough food. The Japanese were just the same to us in the war as they always had been.

After the war was over, seventy bandit soldiers came to our neighborhood, sent by Chen Yi. ${ }^{2}$ Many people were killed when the soldiers stole the people's food. My family didn't get hurt, because I made friends with the bandit soldiers by fixing up a building for them to use when they needed a carpenter. So we became good friends, and they were afraid to hurt my family. Later, the " $2: 28$ incident" happened. An old woman was selling cigarettes illegally in downtown Taibei. There was a fight. Many people died. After the 2:28 incident, things got better. The Japanese and the Nationalist Chinese were about the same, really.

Before the war, I married my wife, A Kim. She had nine children-four girls and five boys. Our first son lives nearby and runs a small dog-meat shop. The second, who is divorced, works in a restaurant. He and his two children live at our house. The third son has a small company, the fourth owns an ironworking business, and the fifth is in the navy. Our four daughters are all married. We married the second to a much older Mainlander because it was necessary to help the family at that time. The Mainlander gave us some money for her; my wife managed the whole thing. The youngest daughter is getting divorced because her husband has a girlfriend.

I got seriously interested in religion only after the Nationalists came. In the war, the gods really showed their power, protecting us from bombs, so I started to believe in them. I didn't really believe when I was young, but I believe more and more as I get older.

About twenty years ago, I began to have spiritual powers: I became a tang $k i(\mathrm{~T}){ }^{3}$ I knew many men who became tang $k i$. Different gods would possess them so they could walk through fire or beat their backs with spiked balls, but not be hurt. I could do those things-I still have the sword I used to use leading the firewalks-but my greatest power was different, and very unusual.

With the help of the gods, my spirit could travel to the underworld to help people solve their problems. I could only ask help there from the ghosts of people whom I had known while they were alive. Ghosts who had been strangers to me in life wouldn't recognize me, and so wouldn't answer questions. A family might be having a lot of sickness or losing money, and

2. Chen Yi was the first Guomindang commander in Taiwan after Retrocession, and later Jiang's scapegoat for 2:28.

3. A spirit medium. 
they'd ask me to go and ask their grandfather why they were so unlucky. Maybe they had been neglecting his spirit, so he was holding back their fortune. I'd ask, and tell them, and they'd make offerings to the unhappy spirit. Then their luck would change. Or a woman would want to know if she would have sons. Down below, each living woman has a flowering tree. Each flower is a child. I couldn't change the number or sex of her children; that is each woman's fate. But I could prop up or replant the tree to make it healthier, foretell the sex of her children from the color of the flowers, and keep weak flowers and branches from falling off.

The world of the spirits is just like here in Taiwan: there are cars, streets, everything just like here. There are even temples. But there are more oldstyle houses than we have now. And the rivers are full of drowned corpses of people who have not been properly buried on earth. People whose zodiac animals are grass eaters, like the ox, can manage there more conveniently than others, as grass grows everywhere, even there, for them to eat. But human food is provided only by the offerings from the living.

While a tang kis spirit is in the underworld, his body on earth acts out the things he does and sees below-like games or operas. He must be careful not to be enticed by women, though. He could lose his power and not be able to get back. When he comes up, he is exhausted. Helpers who interpret for the tang $k i$ should be "strong-fated" and lucky so they can fend off ghosts. If the helper is not like that, the tang ki may not be able to get back to this world. I knew a man who lost his soul that way and died in trance. The helpers have to have special training. I stopped trancing about ten years ago. I am past sixty and no longer have the strength. It's too dangerous.

The images of the gods that helped me do these things are still in my house-I used that as my office then. After I stopped trancing, I still wanted to promote belief in gods, so I began to build up this Earth God temple.

Our little Earth God temple is over three hundred years old. It was there in the time of my eighty-year-old neighbor's grandmother's childhood. When people first settled around here, most of them were farmers. Once, when harvests were bad, they were advised to build a temple for his worship. They had an image made, brought it to a pure and auspicious location, opened the god's eyes, and brought him back to the temple. There's a Madam Earth God, too, of course-you can't have the Earth God without his wife.

Later, they added other gods. After the war, Great Prosperity invited an image of Mazu from Beigang to be a guest at their festival. We borrowed her for a while. The next year, they didn't invite her, so we invited her 


\section{Chinese Working-Class Lives}

ourselves. We did that for some years, then finally had an image of her made and had her eyes opened. She stays here, but she's like a married woman: each year at lunar New Year, she returns to her "mother's home" in Beigang. We've also had images made of Mazu from Lugang and other famous places, and of a Goddess of Mercy from the very old temple at Great Prosperity, which is one of the oldest temples in the island. When we had her eyes opened, the Daoist didn't use blood, because she is a vegetarian.

When a god's eyes are opened with blood-from a white rooster's comb, or sometimes from a duck-the animal is still alive while the blood is drawn. Devotees don't eat the meat of these fowl, but give them to the helpers who open the eyes. Women may not be present at eye openings.

The temple the old people built was very small. In the year of the restoration of Chinese rule, I started to take responsibility for caring for it. I had just moved my family from Great Prosperity over here to this street and noticed the activity at the temple for the Earth God's birthday, which we celebrate in the first lunar month. Some pious person had left oranges and turtle cakes for others to take home to bring their families a peaceful year. Those who took them asked the god for a favor. The next year, those who had taken them returned a gift of food or money to the temple, especially if the god had helped them. It seemed like a good temple, with sincere worshipers. They needed someone to act as head of the temple, so I took on the responsibility. The man who had been in charge before had been the bao zhang for the Japanese, but he didn't do much anymore. So the local people asked me to take over.

About ten years ago, the old roof was so full of termites and the building was so small-only 8 or 9 feet square-that I hired a knowledgeable temple builder to reconstruct and expand it. When I started to take the small temple down, local believers volunteered money to help build it. I didn't go around asking people for money. The people of eight neighborhoods all joined in. I gave a lot myself, and a policeman friend of mine, a rich man, gave NT $\$ 40,000$ (U.S. $\$ 1,000$ ).

After the temple was nicely fixed up, in 1975, we formed a committee to register it with the Ministry of the Interior to change it from private to public property. Then we would not have to pay taxes on the temple's land. We had a big meeting with twelve tables of local household heads who came to choose the committee. Each person contributed NT\$200 (U.S.\$5) to pay for the feast-we didn't eat from the temple's money! It was very democratic, with speeches and voting. My friend the policeman and I were chosen to head the committee, along with twelve committee members and two accountants-one for expenses, the other for income. We filed our application with the police, who sent it up to the City Government, who 
sent it up to the Ministry. After a few months, the Ministry sent an investigator to see if the leadership was respectable, honest, and owned some property. He assessed the temple's value and registered it for us. Now we are an official temple.

I stopped working after I became temple master; I haven't worked as a carpenter now for more than thirty years, though I do a little contracting. My family expenses came from buying and selling houses. I spent most of my time in the temple. People often came to drink "old people's tea." 4 The police would come around and we'd drink tea and I'd get to know them. People were always dropping by - they knew I had an office there.

Every few years, I'd add something new to the temple and the believers always helped with money. I built the roof out in front of the temple so people can leave their offerings on big festival days without fear of rain. I built the altar room on the side to house our many images of Mazu and the "generals" who were forced out of the Xian Gong temple up the road.5 When these things were built, I arranged for Daoists to come and consecrate them. When men began to make more money, their wives wanted to go on pilgrimages to visit Mazu's temples in Beigang, Lugang, and other famous places. So I organized those, which brought many believers to a more sincere worship of the goddess. When young men in our neighborhood asked me how they could organize to serve society, I helped them form a musical group. They played for our festivals and were invited to play for festivals in other neighborhoods. Professor Gates came to some of them and took a lot of pictures of our group. Membership is good for young men. It encourages virtuous behavior and helps them earn a little extra money. The temple has become larger and more beautiful, and has been well supported by local believers, all because they have faith in Mazu and the gods.

Our Taiwanese religion is good for people. The gods teach us to do good, to be honest, to fulfill our responsibilities. They can cure sickness and mental illness, and they help us to prosper. We must show our gratitude by worshiping them. Where people worship the gods, there is less social trouble like robbery and killing. People who criticize religion should think about this.

4. Tea drunk in temples, for recreation.

5. This medium-sized old temple, built on land claimed by the government, was subjected to considerable pressure to close during the early sixties. Though local resistance has kept it open, a government-controlled Buddhist association installed a non-Taiwanese Buddhist priest as temple head. He has attempted to encourage a more patriotic tone in festivals, and has purged the temple of folk images and practices he considers unorthodox. Mr. Go's temple houses these orphan images. 


\section{Chinese Working-Class Lives}

Our neighborhood has an unusual reputation. Many Taiwanese girls have married Mainlander men from a nearby army base, but they have Taiwanese lovers and all three live together. Some of the young men are good fighters and can do what they like. A young relative of mine lives in a household like that, and one of the young men in the musical group was just thrown out by his girlfriend's husband. There are others, too-this place is famous for it. There is some theft here, too. My friend the policeman gave two gold votive offerings to the Earth God, and they have already been stolen by a cat burglar who must have crept in through the window at night. So you see, people need to have the gods to control them.

I am nearly seventy, and Taiwan has changed a lot since I was a child. There are more houses, wider roads, lots more industry. People have washing machines, television, refrigerators. We can keep food for days now. Life is more comfortable. Life is freer, too, because if you have money, you can buy whatever you want. During the war, even if you had money, you couldn't buy things.

It was easier to do street peddling in the Japanese period. The government made it clear where and when you could sell things. Now, there is no set place. If the police want to take your things, they do, and then you have to go to the police station to pay to get them back. There was some crime in the Japanese period, but it was different from today. Today, the government arrests a lot of people, but some just pay them off and go on doing whatever they want. Japanese society was much better, more stable. Under the Japanese, when people did bad things, they went into hiding. Now people who have committed crimes just walk around on the streets, good friends with the police. If you are poor, people laugh at you. If you are rich, no one cares how you got your money.

If a young person asked me how to lead a good life, I would tell him to get a job and work, and don't go into gang life. Try to have a house, get married, and have food to eat: that's enough. When I was young, I wanted to have a house and see my children grow up. My wishes have been achieved. My sons have their own houses, except for the youngest, who is still unmarried. My daughters are married. I live on my savings, and my sons give me money sometimes. I grow a few vegetables in front of my house and help take care of my grandchildren. Live a stable life, month by month-that's the best.

I don't go to our temple much any more. Too many people wanted to be temple master, and things began to change. Now they don't have Taiwanese opera there anymore at festivals, just puppet shows in the afternoon and movies in the evening. The times have changed.

When I was a younger man, I didn't get along well with my wife-I'd go 
to Beitou and bring opera girls back to the house, and she'd get mad. But we're old now. When I go to Wanhua to drink tea, I sometimes take her along. There are some nice tearooms there.

\section{Kho Teklun: Saved by the Buddha}

Mr. Kho, at seventy, is a vigorous and successful old gentleman. Born in Taiwan, he spent his youth competing in the Japanese-run educational system, winning the kind of well-paid and well-respected lower-level government job that was becoming more and more available to Taiwanese in the thirties. When the arrival of the Nationalists erased the value of his Japanese-language education, he turned to small business as a way of earning a living. A capable man, he did well at that, too, for he chose construction-one of the few reliably expanding businesses of the fifties. With a much-loved wife, whose death is still too painful for him to discuss, he raised two prosperous sons and married off three well-educated daughters. Perhaps because of the breadth of his early education, these traditional fulfillments were not enough. In his forties, he turned his mind to religion.

Before I was able to meet Kho Teklun, I had heard of him for years through my old friend Ong Siukim as a kind of guardian angel to her unhappy family. Motivated by religious belief resulting from his conversion to a Japanese form of Buddhism, Mr. Kho quietly seeks out and helps those in trouble, persuading them, when he can, to embrace his religion. Because he sounded like an interesting and knowledgeable man, I hoped to meet him, trying several times on my first field trip to have Miss Ong arrange this. When I was unsuccessful, I concluded—rightly - that he was unwilling to know me. Before long, I discovered why.

The Buddhist sect that Mr. Kho had joined and was quietly propagating is illegal in Taiwan, banned by the government. It is Soka Gakkai, a religion that became tremendously popular in Japan after World War II among working-class people and new migrants to the cities. More than a religion, Soka Gakkai has amassed considerable property, and successfully backs the populist Clean Government party in Japan's national politics (White 1970). The Nationalist government in Taiwan refuses to permit the emergence of a religion with such potential for social and political power; in consequence, the sect and its members remain secretive about their organization and cautious about connections with strangers. My eventual success in gaining hs confidence was due to Miss Ong vouching for me as, by now, an old friend. 
Mr. Kho receives his many visitors in a cluttered living room above the small first-floor grocery his family runs. The clutter is fascinating evidence of a well-rewarded life: framed Japanese-language school certificates, official awards, gracefully phrased calligraphic couplets celebrating family and business events, and souvenirs of travel and meetings with important people. Among the treasures are family heirlooms, such as his grandmother's three-inch-long slipper for a foot bound in infancy, a lovely teapot from an ancestress' dowry, a porcelain wine bottle from a special feast.

Fine-featured and iron-gray, Mr. Kho looks years younger than his age. His energy carries him on long walks nearly every day on business or charitable errands, but he is at home most afternoons after the midday nap, which all in Taiwan try to squeeze into their routines. Visitors, mostly younger men seeking favors or fellow members of Soka Gakkai, frequently interrupted or terminated our interviews.

Skill at managing a thick skein of human relationships is the most prized talent in Chinese society. It allows its possessor to create a sufficiently wide network of well-placed people to achieve his ends-any ends-gracefully, efficiently, and without excessive expense. Do you need a team of reinforced-concrete workers to put up a building? A man is found who is sufficiently obligated that he will reliably supply them, at a reasonable price. Are you in difficulties with the police? Someone's uncle is related to the police chief, and will speak to him. Do you want to buy a refrigerator? An old schoolmate's son will sell you one wholesale. Would you like your less-than-brilliant son to enter a respectable college? The right combination of cash and acquaintanceship can, perhaps, achieve this end. Is becoming a U.S. citizen your goal? An old friend's elder brother now with the diplomatic mission in the States can get you on a list for a green card. A person's power is based on his ability to deliver a well-disposed contact to someone with a request - who, in turn, becomes an indebted source of future favors for other supplicants. The man in the middle, "the person who has a way," gains with each transaction, and spreads his network ever farther.

This is a demanding life. Men who use these networks to become elected politicians are expected by their constituents to be on twenty-four-hour call to solve their problems; a popular mayor boasts that he sleeps in his office, supremely available. Mr. Kho is only an amateur, not very wealthy, and holder of no high office. He could not (I believe) help anyone emigrate to the United States, or bribe a friend's son into a university. But to anyone who can presume on his acquaintance, he is a valuable source of connections and information about who is who, and who can do what, in local government and civil service, in the construction trades in south Taibei, and in a number of other useful areas of expertise. 
Unlike many men of his age and in his line of work, Mr. Kho has kept clear of the underworld of gangsterism, mainly for religious reasons. This may be why the political career of this wise and influential man has been limited to election to a minor neighborhood post. Spreading the blessings of his religious belief to others also absorbs much of the time a political career would have required him to spend mingling with the marginal characters whose vote-buying activities are essential to the Nationalists' continued success. While Mr. Kho clearly regrets his exclusion from public power, he sees mostly venality in those who do hold it. By choosing to dedicate his time to the practice and propagation of an illegal Japanese sect known for its political and social activism, Mr. Kho rebels, a little, against the political system that so changed his life.

My ancestors came from An Qi county of Fujian province. They were surnamed Kho. About one hundred years ago, my great-grandfather came to north Taiwan with his wife to cultivate sweet potatoes and tea on uninhabited land. They planted sweet potatoes first, to have something to eat, and slowly began to raise tea, pigs, chickens, and ducks. They worked very hard.

The Mountain People used to kill us plains people to offer our heads as sacrifices. Therefore, every day before leaving the house, our ancestors asked the god's guidance. If they didn't get a positive answer from thrown divining blocks they stayed in that day! If the Mountain People saw you, they'd kill you. We had no guns or knives, but outsmarted them by running away. There were tigers, bears, and bandits then, too; those were harsh times. Our people ate mountain products, and there were no good things to eat.

Then, in the time of my grandfather, Kho Toakim, the Japanese came to Taiwan and took control. The Japanese fought the Aborigines back into the mountains, to Mount $\mathrm{A} \mathrm{Li}$, to Wulai, places like that. From this began a time of peace.

Grandfather grew tea, which is very hard work. He slept only four hours a night so he could work to earn money to buy his land, as people were not allowed simply to occupy the uninhabited areas without paying for them. He grew rice and tea, and built a house of straw and clay. Snakes used to come into the house sometimes.

In Grandfather's time there was peace, but the Japanese made living harder for us in some ways. They taxed at a high rate and discriminated against us Chinese people. They made Taiwanese build the public buildings, roads, and bridges made out of layers of soil, then wood, then clay. There were land taxes and household taxes, though the taxes were not as 


\section{Chinese Working-Class Lives}

heavy as they are now. Mostly the Japanese made use of our labor by requiring people to work without pay. The land tax on cultivated and uncultivated land and houses for our family came twice a year-ten yen each time.

At that time, women bound their feet-the smaller their feet became, the more admirable they were thought to be. I still have my mother's shoes, which are only three inches long. Even in the countryside, women did this. Their work was cooking, caring for children, in the house because most women didn't go into the fields. Only servant women didn't bind their feet. The Japanese forbade this custom, however, which they said was unhealthy. Taiwanese people couldn't oppose the prohibition against foot binding, although they were angry about it, because the Japanese had a good system of household registration, and they inspected every house for illegal foot binding, for vaccination, and even for cleanliness.

In school, you were equal with the Japanese if you were clever and got high grades. If you graduated with good grades, you could get high official positions-in the police, as mayor, as head of a school. They didn't discriminate in this, because they were afraid we would rebel.

My grandfather started to buy fields around here in Xindian, as he was making a good living. At that time, agriculture was all done with human labor. Men cultivated fields and built irrigation works by themselves, until the time of my father. Then the Japanese built irrigation works, charging fees twice a year for the use of the water.

When he was young, my father was a guard protecting a Japanese area against Aborigine attacks. He got a gun, a uniform, and a salary and was nearly killed by one of the Mountain People when he was thirty-seven. After he married at thirty eight, he stopped being a guard to grow tea and rice. When we were seven or eight years old my two brothers and I began to help in the fields and to watch the water buffalo. We didn't have shoes, so our feet nearly froze in winter. Father bought an old straw and mud house, and later he rebuilt it of bricks.

The Japanese interviewed my father in an official search for model farmers, and rewarded him for his hard work. We were prosperous when others were poor because we worked ourselves so hard, didn't hire labor, and saved money. So father was appointed baozhang. We then had between three and four $j i a^{6}$ of land in this area.

About then, my eldest brother was also successfully growing tea, but he drank some ditch water, which gave him tuberculosis. He died at fiftyeight, with five children-there was no cure for his illness during the

6. One jia equals approximately two and one-half acres. 
Japanese period. My younger sister also died, of throat cancer. I had malaria at the age of twenty-six, and it almost killed me. Later the Japanese eliminated malaria, but in the early years of my life, many illnesses were fatal.

When I was young, there were no nearby hospitals and no public health stations such as we have now; if you were really sick, there was Taiwan University Hospital in town. Both Western-style and Chinese pharmacies dispensed medicines according to the diagnosis of the pharmacist. Most were traditional Chinese pharmacies. The Western ones were brought by the Japanese. The Japanese stationed public doctors, who worked out of offices in their houses, at Xindian and at many other small towns. Some of these doctors were Japanese, some Taiwanese. Their medicines were cheaper than those in the pharmacies. People doctored themselves with herbs unless they were very ill and rarely went to doctors.

My father sent us three brothers to school, but our two sisters didn't have the opportunity to study. I remember being very afraid on my first day at school. I wanted to get out of there and follow my mother home! If there hadn't been so many others there, I would have cried. Until I was in the fifth or sixth grade, I was always in fights.

In the first grade, we were allowed to speak Taiwanese, but by the end of the fourth grade, everything was in Japanese. If we spoke any Taiwanese at school after that, we were beaten with a wooden paddle. From there, I took the entrance examinations, passed, and went on to three years of middle school, where four of my teachers were Taiwanese, and two Japanese, four male, and two female. We wore uniforms and shoes and paid a school tuition fee. If a person could pass the entrance exam but was too poor to pay the tuition, he (or she) could apply to the education office and have the fee waived. This money came from our taxes. Tuition was fairly cheap-2.6 yen a semester, when pork cost less than 20 sen a pound. Students had to supply their own books. The middle school had a small health station, too.

After graduating from middle school, I passed an exam to enter a threeyear government-run tea agronomy institute. There were two to three hundred students, half Taiwanese and half Japanese. The Japanese were trying to improve the quality and quantity of Taiwanese teas, which were already very famous. I thought this would be interesting and wanted to study there, even though there was no guarantee of a job afterward. Before graduation we had to undergo three months of hard practical training, going out to the countryside to instruct farmers in tea growing. Those who passed with high scores and good recommendations were sent by the principal to jobs in the tea sections of various administrative offices in north Taiwan. My grades were high, and I got good recommendations from a 


\section{Chinese Working-Class Lives}

Japanese friend, from a teacher, and from a rich man in our village, so I was given a job in a high-level office here in Xindian. I eventually became chief of the agricultural section.

The government sent me to Hainan Island for a while when I was twentyseven, to supervise the agricultural practices of the many Taiwanese who were growing rice there. My back gave me such trouble, though, that they had to send me home. At thirty, I married my wife, whom I had met as a tea-picking maiden in Xindian. Tenants farmed my fields, and I continued my work in tea agronomy until after World War II, when the present Chinese government arrived.

As World War II became worse, Taiwanese people were ordered to serve in the military in the South Pacific where a lot of them died of malaria. My second elder brother was sent abroad and suffered great hardships.

It was hard to survive during those years. As soon as your harvest was dried, you handed it over to the government, and they gave back a daily ration of six ounces of rice for each person in your household. You would be shot if you kept rice at home secretly. There was not enough rice to eat, so we grew sweet potatoes to feed ourselves-we were allowed to keep those. The Japanese shot a few people as an example, so people dared not keep the rice. The authorities knew how much rice could be harvested from one jia of land, so there was no deception.

War is a great misfortune for people. When people are satisfied with what they have, there will be no more war. I don't blame the Japanese for the war, though, and I'm not angry with them, even though they killed Taiwanese, because they were trying to make the Japanese empire great.

The relationship between Taiwanese and Japanese people was not a simple one. The Japanese are a very civilized people and did many things to build up Taiwan, improving life here very much. At the same time, we were not treated as equals. We were an occupied country, more like their adopted sons than their own sons. Even though I studied Japanese, I was always made to feel different. Our surnames were different from theirs, and this marked us as Taiwanese, no matter what we did to learn Japanese ways. During World War II, Taiwanese were told to change their surnames to Japanese ones, but by then, I didn't want to. Especially during the war, we became conscious of our Chinese origins as we heard of the fighting between Chinese and Japanese on the mainland. After all, each generation is taught where their ancestors came from in China, so I grew up with knowledge of my Chinese origins, even while my life was somewhat Japanese.

In 1945 Japan surrendered. I couldn't write Chinese, so I had to quit my job. I had no capital, but we fixed up a house that had been bombed to live 
in with our two children. Though my land was tenanted, I couldn't get any money from it - the tenants were too poor. So I started a construction business, and sometimes the gold just rolled in because so much rebuilding was necessary after the war. After a year in the construction business, I started a grocery store at South Gate in Taibei and ran that till I was fortynine.

Then I got sick. My face and body turned yellow, and I nearly died. So I came back to my wife's family to rest up, because the doctor said nothing could be done to cure me. The necessary medicines were simply not available in Taiwan then.

Just then, I read in a newspaper about a sutra in Japan which could save people if they repeated it. I learned the sutra from the Japanese newspapers that we could still get then, and repeated it three or four times every day. When I returned to my doctor, he couldn't believe I was still alive. The meaning of the sutra is that you can become harmonious with the great universe. Reciting the sutra improves our characters, making up for our personal shortcomings. I've prayed using this sutra from when I was fortynine until now, in my seventieth year. No one taught me, but I often buy books to study more deeply in religious matters. Now I am healthy enough to carry a fifty-kilo bag of rice to the second floor.

I extend my life by praying "o mi to fo," by reciting the special sutra of our faith. There's no organization for this religion in Taiwan, but there's a school of it in Japan. It is proscribed in Taiwan because it is Japanese. I have taught a little of it to a few people, not asking for donations, and some of us help poor people. Otherwise, who would save the disabled, like our crippled friend Miss Ong? After she began to recite this sutra, she had the chance to marry, and now she has a son.

There is freedom of religion here in Taiwan. What this means is that the government forbids evil religions, and we are not allowed to organize people who pray using this sutra-it is against the law. We preach our belief by personal contact, and by helping people. We don't need to organize or evangelize. I don't know how many believers there are around here; perhaps not many, but it is hard to know.

Folk religion is naive by comparison, using pictures and statues as objects of worship. Buddha said people could do this for a thousand years, after which there would be a new way, taught by a new sutra. The religion I follow, and the God, are the same as this older form of Buddhism, only clearer, just as the sutra is the same, though it was once Sanskrit and has been translated into Chinese. We followers of Soka Gakkai worship a different state of the Buddha with a different sutra.

This faith is a great improvement over traditional folk religion because it 


\section{Chinese Working-Class Lives}

has a systematic explanation of things. Our Fahua Sutra divides humans into ten categories. We have a choice which category to belong to-you can be good, do right, if you choose. This religion, originally Indian, spread to Japan and is now spreading even in the United States. There is a new Buddha for each thousand years. The next new state of the Buddha will be in Japan, because Japan is in the center of the solar system, and because it is a nation without knowledge of the true way of religion and therefore needs a new path to follow. So a Buddha will be born there as a fisherman, among the common people, after which Soka Gakkai will become the main religion of Japan and the world.

From the Fahua Sutra, you can learn to be a virtuous person. You simply recite the sutra as many times as you need to. It's necessary to be educated, so as to be able to read the sutra, of course. As you worship, you train yourself, asking yourself whether you are filial and honest, and if you are behaving legally and helping to preach our discipline.

If anyone asks me why I am so healthy and long-lived, I tell him it is because I recite our sutra, and I urge him to do so, too. Through personal contact and example, we can help others to have a better chance in life by behaving well. If all humans did this, believing in Buddha, there would be peace instead of war. War is a terrible thing.

Traditional religion is not actually bad-I was always in the parades for the gods at the main Xindian temple when I was young, and I enjoyed the feasting and opera-but its goals are simple. People enjoyed the entertainment, but now there are many forms of recreation, like hiking and exercise, which are better for you. Worshiping in order to hold big feasts makes no sense now that people eat well every day. This old form of religion is regressive superstition. It is foolish to mix up the worship of Buddha with that of the old gods. That's naive.

After World War II, for a time people became very evil, robbing, killing, and insulting women. This was the result of the population increase as people fled from the mainland. Many were ambitious, greedy, and wanted to have a good life without working hard. In education, a prince was the same as a common person under the Japanese; under the Chinese, this was not so. The Japanese law was compulsory, binding on everyone. The way Chinese law is applied depends more on who you are.

Right after the surrender, on October 25, 1945, when the Chinese government had not yet reached Taiwan, we educated Taiwanese took over all official business as the Japanese gradually returned home. We ran the provincial, county, and local levels of government for about a month until General Chen Yi arrived with his soldiers.

Those troops behaved abominably. Everything bad you can think of, they [200] 
did. Before all the Japanese left, they opened their storehouses of several years of food and supplies to give to the people, as there would be no more imports. A lot of that was looted by the Mainland troops.

By 1947 the behavior of the Mainland people was so bad that the February twenty-eighth uprising-2:28—occurred as Taiwanese resisted the corruption and oppression of the Mainlanders. I was an elected Neighborhood Head in South Gate at the time, a part of Taibei that saw much fighting, as Mainlander soldiers shot civilians and Taiwanese attacked Mainlanders with swords. I used my position to keep people in our neighborhood from killing Mainlanders; no good could come of it. People were being shot indiscriminately in the street by troops as the days went on. It was months before all the resisters were killed or imprisoned.

General Chen Yi lied about these events, saying that the Taiwanese had revolted, but we were only defending ourselves against his troops. General Bai Chongxi ${ }^{7}$, chief of the Defense Department, went out and moved among the people, standing in a bus line in Jilong, and watching people work as usual. So he knew that General Chen had lied. Later, General Bai distributed awards to people like myself who did not fight against the Mainlanders.

After $\mathrm{Mr}$. Chen Cheng ${ }^{8}$ became governor in 1949 , life improved. He was a responsible official, who went into the streets and markets and temples to see the quality of people's lives, to make reforms and improvements. Even the poor had rice again. When he died, he was greatly mourned. People walked five days and nights from southern Taiwan to come to his funeral. That is the right kind of official; these time-servers who wait around in offices to collect their salaries are bad officials who harm the people.

Another very serious problem after the Chinese took over was inflation. Because they wanted Taiwan's wealth, the Japanese had changed our original money system based on gold and silver, giving us paper money in its place. There were various denominations, and people saved the paper money in banks and postal savings accounts when they could afford to.

After Japan lost its battle, for a while we used Japanese money, but it was said it would soon be declared valueless. The Chinese government set a period of a month or two during which people could exchange their Japanese cash for Chinese notes, but it wasn't possible to draw savings out and exchange that. Some people read the announcement; some didn't.

7. An official of known integrity, General Bai Zhongxi is remembered as an opponent within the Mainlander group of the dominant Jiang family.

8. An unusually respected Nationalist official, Chen Cheng served as governor and in other high Taiwan offices from 1949 to 1963. 


\section{Chinese Working-Class Lives}

Some people, peasants mostly, heard that all the Japanese money was valueless after surrender, and burnt even their cash, losing everything. All insurance savings were also lost. Some of our officials suggested that Japan ought to return the money people lost in banks, postal savings, and insurance, but nothing was done. Japan lost the war, after all, and they were broke.

I was in Taibei during that period, building and repairing houses. I had lost savings, but managed to make a living. Some people with tea and rice to sell did well.

All kinds of sharp dealings were going on in the late forties. Two private mainland banks with very large capitals began to offer high interest to their customers-a thousand a month interest on a ten thousand deposit, ten thousand on a hundred thousand, and so on. People, greedy to get the interest sold land, rice fields, and houses to put money in these banks. They thought they'd just sit and live on the interest without having to work. But the inflation had already begun. A sack of rice cost 100,000 Old Taiwan Dollars today and 150,000 tomorrow. Money was worth less and less. Then the banks broke, and people couldn't get even their capital back, let alone the promised interest. Public banks gave you a check for your money; private ones nothing. I had put over five million in a private bank, and lost it all. Where the bankers went with it, I never learned.

As I built and repaired houses, everything cost more each day. It was hard to figure how much to charge in order to make a profit. Today I paid a wage worker OT $\$ 500$, tomorrow OT $\$ 700$, the next day OT\$800. I was sure that the government would solve the problem sooner or later, so I stopped working as a builder for six or seven months rather than lose money at it. Then Mr. Chen Cheng came, in 1949. He called in the Old Taiwan Dollar currency and issued New Taiwan Dollars at a rate of OT $\$ 40,000$ to NT $\$ 1$. The worst of the inflation lasted three or four years, but the currency became stable only by the mid-1950s.

When the Chinese came, there was a high rate of tenancy in Taiwan. Some landlords just sat and waited for the harvest, while their tenants had to struggle to survive. After paying rent to the landlords and tax to the government, they had nothing left for themselves.

Mr. Chen Cheng reformed the tenancy situation with the "three-sevenfive" law under which landlords could receive no more than 37.5 percent of the harvest. Later, the government bought up tenanted land in excess of three $j i a^{9}$ from landlords and sold it to the tenants. The landlords were

9. Three jia equal approximately 7.2 acres.

[202] 
angry about the land reform, but what could they do about it? No one dared oppose the government after the events of $2: 28$. The reform was peaceful, and within ten years the government paid the landlords off, though at a price much below what the land was actually worth. So the landlords all lost out, despite what they were paid-a real reversal, since they formerly had been so greedy.

My fields in Xindian had long been cultivated by my relatives, so the government considered this family land, not tenancy, and left us alone. Even now, my nephews work that land and give me whatever share of the harvest they wish. I'm glad I kept the land rather than selling it to get capital for my business. It's been a small source of income, and I've been able to help my relatives make a living, too.

I've been in the construction business ever since the early fifties, and members of my family have always kept a shop. My wife managed that for years-it was her shop, really. After she died three years ago, my eldest daughter-in-law took over. She's away now, touring southeast Asia, so things are in a bit of a muddle.

Some years have been better than others in the building business. There's a lot of red tape in land transactions because the government doesn't want good agricultural land sold off at random any more for construction. Four men were tried and executed this summer for illegally rezoning land. In the sixties it was easier because the loss of agricultural land wasn't seen as such a problem then. The economy was really beginning to do well, too, and people needed houses. I built a lot thenemployed dozens of laborers all the time, and earned enough to keep my family and educate my children. There were heavy expenses, too, though. Labor got dearer, the cost of cement went way up during the Vietnam war, because we were selling it to the Americans and South Vietnamese. A contractor has to give a lot of expensive banquets to keep building inspectors and officials who grant various licenses on good terms with him. So I never became rich.

By the time I reached my sixtieth birthday, in 1970, I decided to retire. My son was grown and capable, with a good job in a chemical company; my son-in-law had his own construction firm in Taizhong. I wanted to devote more time to studying our religion. I kept my hand in-I built this building just five years ago, on the site of our old house-but I slowed down.

Now I have time to observe life in a relaxed way. People come to see me, and sometimes I can help them by getting them a job, introducing them to someone, lending them a little money, giving some advice. The local people have elected me Neighborhood Head for many years now, and I 


\section{Chinese Working-Class Lives}

have the responsibility of informing them of government and party directives, of holding citizens' meetings, and of making sure the neighborhood people keep their household registration records up to date.

When the central government of China left the mainland in 1949, they planned to establish a model province here. In recent years, this has begun to come true as life gradually becomes easier. At the beginning, though, we often regretted losing our place in the Japanese empire. Each nation has its fate, just like a person-sometimes good, sometimes bad. I have seen many changes in Taiwan during my lifetime. Education is more widespread but less effective now. People generally are less disciplined, both those above and those below. But some things have remained the same. Under the Japanese, we Taiwanese could form businesses as we liked, but we were not allowed to get into politics. Under the Chinese government, we have done very well in business, but we are still not very active in politics. We are free to do so now, but, for myself, I am too old. It is the young men's turn now. 